\title{
Research on Mechanical Properties of Adhesive Bonds Reinforced with Fabric with Glass Fibres
}

Jan Zavrtálek, Miroslav Müller

Faculty of Engineering, Czech University of Life Sciences Prague. Czech Republic. E-mail: zavrtalek@tf.czu.cz, muller@tf.czu.cz.

In this paper the mechanical behaviour of structural two-component epoxy adhesives in $\mathrm{T}$-joints is experimentally investigated. Laboratory experiments were performed on standardized test specimens of structural carbon steel S235J0 made according to standard ČSN ISO 11339.

The aim of experiments was to confirm or disprove a hypothesis about a possibility to increase the adhesive bond peeling strength by means of an interlayer from glass fibres.

The research was focused on an effect of an improving a resistance of the adhesive bond stressed by peeling by adding an interlayer created by fabric from glass fibres. The testing of these properties was performed in accordance with standard ČSN EN ISO 11339. An epoxy resin was used as the adhesive for connecting adherents created by sheets of steel. The fabric from glass fibres of the type $E$ in a plain weave was added as the reinforcement for creating the composite bond. For optimization of properties of the composite bond it was used various weight in grams of fabric in the extent of $80,110,160,220 \mathrm{~g} / \mathrm{m}^{2}$.

Keywords: Adhesive bond strength, peeling strength, T-joint, two-component epoxy adhesives

\section{Acknowledgement}

This paper has been done when solving the grant IGA TF (2015:31140/1312/3106).

\section{References}

[1] PING HU, QI SHAO, WEIDONG LI, XIAO HAN. (2012). Experimental and numerical analysis on load capacity and failure process of T-joint: Effect produced by the bond-line length. In: International Journal of Adhesion and Adhesives, 38: 17-24.

[2] SALIH AKPINAR, MURAT DEMIR AYDIN and ADNAN ÖZEL. (2013). A study on 3-D stress distributions in the bi-adhesively bonded T-joints. In: Applied Mathematical Modelling. 37.10220-10230.

[3] MESSLER, R. W. (2004). Joining of materials and structures from pragmatic process to enabling technology. Burlington: Elsevier.

[4] HABENICHT, G. (2002). Kleben: Gundlagen, Technologien, Anwendung. Berlin: Springer.

[5] CIDLINA, J., MÜLLER, M., VALÁŠEK, P. (2014). Evaluation of Adhesive Bond Strength Depending on Degradation Type and Time. Manufacturing Technology, 14(1): 8-12.

[6] MÜLLER, M. (2014). Setting of causes of adhesive bonds destruction by means of optical analysis. Manufacturing Technology, 14(3): 371-375.

[7] MÜLLER, M. (2013). Research of Liquid Contaminants Influence on Adhesive Bond Strength Applied in Agricultural Machine Construction. In: Agronomy Research, Vol.11, pp. 147-154.

[8] MÜLLER, M. (2011). Influence of Surface Integrity on Bonding Process. In: Research in Agricultural Engineering, Vol. 57, pp. 153-162.

[9] RUDAWSKA, A. (2014). Selected aspects of the effect of mechanical treatment on surface roughness and adhesive joint strength of steel sheets. In: International Journal of Adhesion and Adhesives, Vol. 50, pp. 235-243.

[10]NAITO, K., ONTA, M., KOGA, Y. (2012). The Effect of Adhesive Thickness on Tensile and Shear Strength of Polyimide Adhesive. In: International Journal of Adhesion \& Adhesives, Vol. 36, pp. 77-85.

[11]KARBHARI, V. M., \& ABANILLA, M. A. (2007). Design factors, reliability, and durability prediction of wet layup carbon/epoxy used in external strengthening. Composites Part B: Engineering, 38(1), 10-23.

[12]MAHERI, M. R. (2010). The effect of layup and boundary conditions on the modal damping of FRP composite panels. Journal of Composite Materials, 45(13), 1411-1422.

[13]NOVÁK, M. (2012). Surfaces with high precision of roughness after grinding. In: Manufacturing technology. Vol. 12 , pp. $66-70$. 
[14]NOVÁK, M. (2011). Surface quality of hardened steels after grinding. In: Manufacturing technology. Vol. 11, pp.55-59.

[15]HOLEŠOVSKÝ, F., NÁPRSTKOVÁ, N., NOVÁK, M. (2012). GICS for grinding process optimization. In: Manufacturing technology. Vol. 12, pp. 22-26.

[16]HRICOVA, J. (2014): Environmentally conscious manufacturing: the effect of metalworking fluid in high speed machining. In: Key engineering materials. Vol. 581, pp. 89-94.

[17] ŤAVODOVA, M. (2013). The surface quality of materials after cutting by abrasive water jet evaluated by selected methods. In: Manufacturing technology. Vol. 13, pp. 236-241.

[18]RUGGIERO, A., VALÁŠEK, P., MEROLA, M. (2015). Friction and wear behaviors of Al/Epoxy Composites during Reciprocating Sliding tests. In: Manufacturing technology, Vol. 15, No. 4, p. 684-689.

[19]MÜLLER, M., VALÁŠEK, P. (2012). Degradation medium of agrokomplex - adhesive bonded joints interaction. In: Research in Agricultural Engineering, Vol. 58, pp. 83-91.

[20]MÜLLER, M. (2015). Influence of loading speed on a change of parameters of adhesive bonds based on cyanoacrylates. In: Research Agricultural Engineering, Vol. 61, No. 4, pp. 177-182.

[21]MÜLLER, M. (2015). Research on Surface Treatment of Alloy AlCu4Mg Adhesive bonded with Structural Single-component Epoxy Adhesives. In: Manufacturing Technology, Vol. 15, No. 4. pp. 629-633.

[22]KOTOUSOV, A. (2007). Effect of a thin plastic adhesive layer on the stress singularities in a bi-material wedge. In: International Journal of Adhesion \& Adhesives, Vol. 27, No. 8, pp. 647-652.

[23]GRANT, L. D. R., ADAMS, R.D., LUCAS da SILVA F.M. (2009). Experimental and numerical analysis of singlelap joints for the automotive industry. In: International Journal of Adhesion \& Adhesives, Vol. 29, No. 4, pp. 405413.

Copyright @ 2016. Published by Manufacturing Technology. All rights reserved. 